Prepared in cooperation with the City of Cedar Rapids

\title{
Total Phosphorus Loadings for the Cedar River at Palo, lowa, 2009-20
}

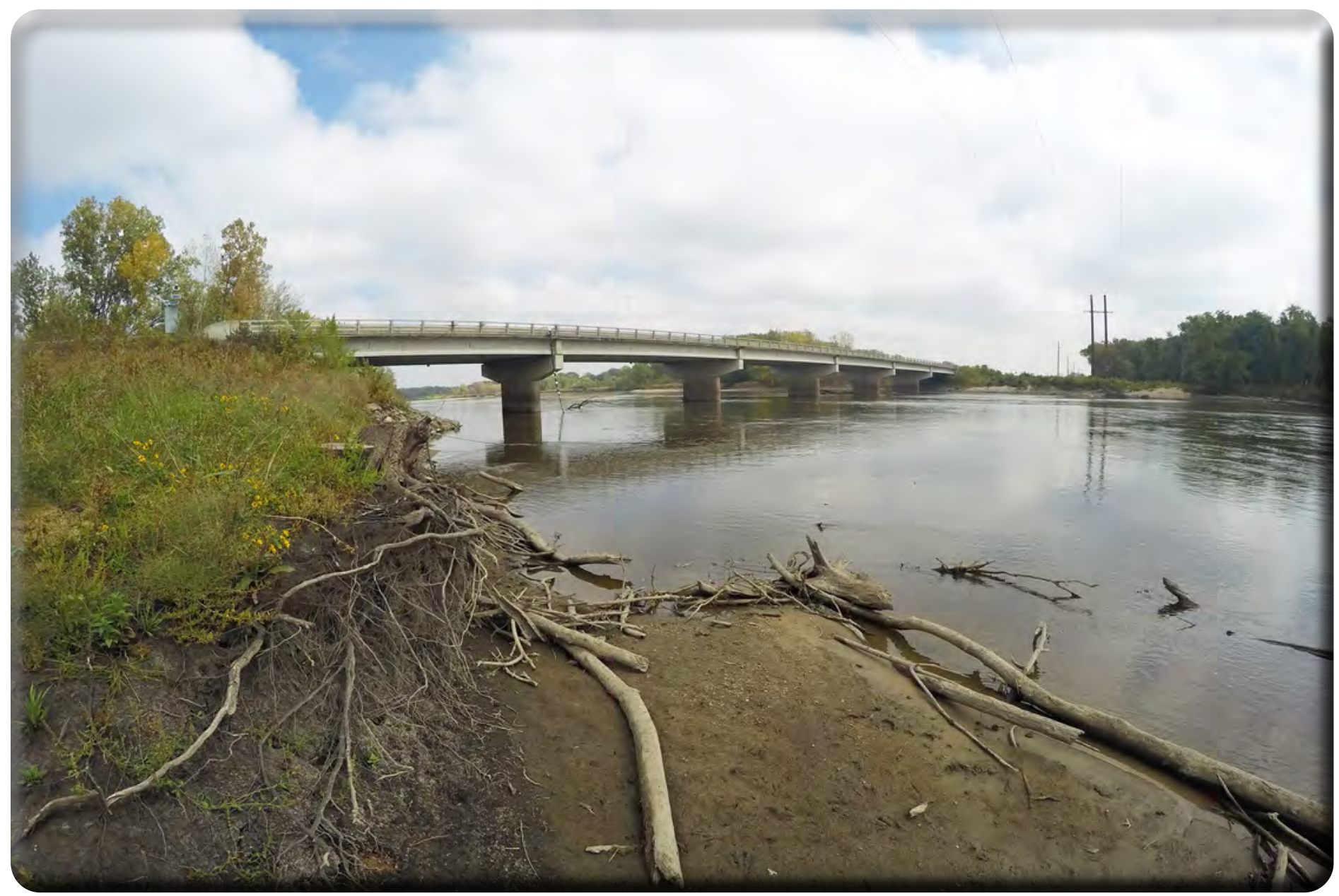

Scientific Investigations Report 2021-5127 
Cover: Photograph showing Cedar River at Palo, lowa, during low streamflow on September 19, 2017.

Back cover: Photographs showing (top) Cedar River at Palo, lowa, with continuous water-quality sensors during flood on September 26, 2016, and (bottom) Cedar River at Palo, lowa, with continuous water-quality sensors during low-flow conditions on September 19, 2017.

Photographs by Stephen J. Kalkhoff, U.S. Geological Survey. 


\section{Total Phosphorus Loadings for the Cedar River at Palo, lowa, 2009-20}

By Jessica D. Garrett

Prepared in cooperation with the City of Cedar Rapids

Scientific Investigations Report 2021-5127 


\section{U.S. Geological Survey, Reston, Virginia: 2021}

For more information on the USGS - the Federal source for science about the Earth, its natural and living resources, natural hazards, and the environment—visit https://www.usgs.gov or call 1-888-ASK-USGS.

For an overview of USGS information products, including maps, imagery, and publications, visit https://store.usgs.gov/.

Any use of trade, firm, or product names is for descriptive purposes only and does not imply endorsement by the U.S. Government.

Although this information product, for the most part, is in the public domain, it also may contain copyrighted materials as noted in the text. Permission to reproduce copyrighted items must be secured from the copyright owner.

Suggested citation:

Garrett, J.D., 2021, Total phosphorus loadings for the Cedar River at Palo, lowa, 2009-20: U.S. Geological Survey Scientific Investigations Report 2021-5127, 15 p., https://doi.org/10.3133/sir20215127.

Associated data for this publication:

U.S. Geological Survey, 2021, USGS water data for the Nation: U.S. Geological Survey National Water Information System database, accessed February 25, 2021, at https://doi.org/10.5066/F7P55KJN.

ISSN 2328-0328 (online) 


\section{Acknowledgments}

The author would like to thank the staff of the City of Cedar Rapids Utilities Water Division for providing support for this project.

Special thanks to U.S. Geological Survey employees Stephen J. Kalkhoff and Shannon M.

Meppelink for installation, sample collection, and site operation and Stephen J. Kalkhoff and

Adam E. Manaster for providing colleague reviews. 



\section{Contents}

Acknowledgments ……...................................................................................................................

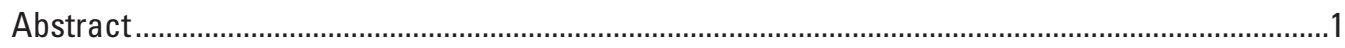

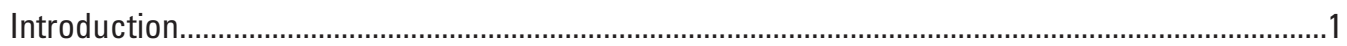

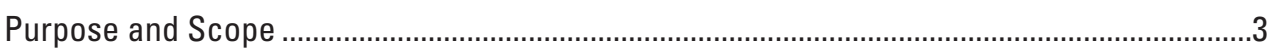

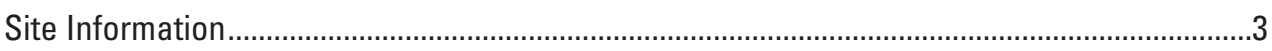

Methods for Data Collection and Computation ………............................................................

Continuous Water-Quality Data Collection and Computation ......................................................

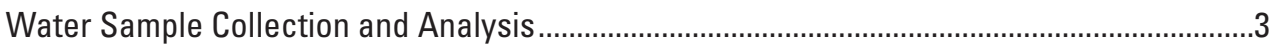

Methods for Computation of Concentrations and Loads ..........................................................

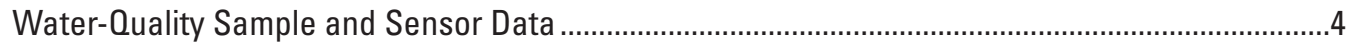

Continuous Water-Quality Time-Series Data to Compute Nutrient Loadings....................................7

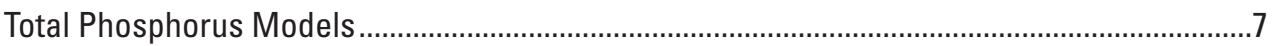

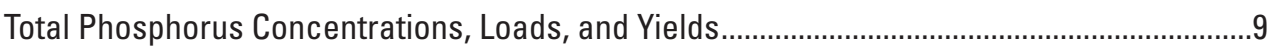

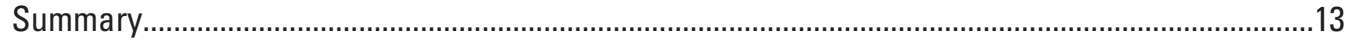

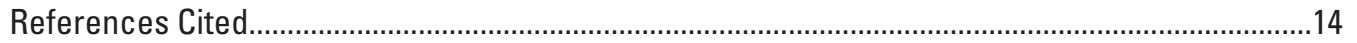

\section{Figures}

1. Map showing selected U.S. Geological Survey streamflow-gaging, nutrient, and turbidity monitoring station study sites in the Cedar River Basin in lowa ........................2

2. Graphs showing duration curves with calibration samples, Cedar River at Blairs Ferry Road at Palo, lowa ...........................................................................................

3. Graphs showing sampled and estimated total phosphorus values for four models, Cedar River at Blairs Ferry Road at Palo, lowa ....................................................

4. Graph showing annual total phosphorus loads relative to phosphorus-reduction benchmark and 45-percent reduction goal...................................................................12

5. Graph showing the relation between annual runoff and total phosphorus yield from the Cedar River at Blairs Ferry Road at Palo, lowa. .13

\section{Tables}

1. Summary of calibration samples and time-series data, Cedar River at Blairs Ferry Road at Palo, lowa ...

2. Total phosphorus concentration regression models, Cedar River at Blairs Ferry

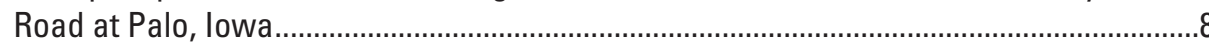

3. Summary of total phosphorus concentrations, loads, and yields for the Cedar River at Blairs Ferry Road at Palo, lowa. 


\title{
Conversion Factors
}

U.S. customary units to International System of Units

\begin{tabular}{|c|c|c|}
\hline Multiply & By & To obtain \\
\hline \multicolumn{3}{|c|}{ Length } \\
\hline inch (in.) & 2.54 & centimeter $(\mathrm{cm})$ \\
\hline \multicolumn{3}{|c|}{ Area } \\
\hline square mile $\left(\mathrm{mi}^{2}\right)$ & 259.0 & hectare (ha) \\
\hline square mile $\left(\mathrm{mi}^{2}\right)$ & 2.590 & square kilometer $\left(\mathrm{km}^{2}\right)$ \\
\hline \multicolumn{3}{|c|}{ Flow rate } \\
\hline cubic foot per second $\left(\mathrm{ft}^{3} / \mathrm{s}\right)$ & 0.02832 & cubic meter per second $\left(\mathrm{m}^{3} / \mathrm{s}\right)$ \\
\hline ton per day (ton/d) & 0.0105 & kilogram per second $(\mathrm{kg} / \mathrm{s})$ \\
\hline ton per year (ton/yr) & $2.8747 \times 10^{-5}$ & kilogram per second $(\mathrm{kg} / \mathrm{s})$ \\
\hline \multicolumn{3}{|c|}{ Mass } \\
\hline ton, short $(2,000 \mathrm{lb})$ & 0.9072 & metric ton $(\mathrm{t})$ \\
\hline \multicolumn{3}{|c|}{ Yield } \\
\hline pound per acre per year (lb/acre/yr) & 112.1 & $\begin{array}{l}\text { kilogram per square kilometer per day } \\
\qquad\left(\mathrm{kg} / \mathrm{km}^{2} / \mathrm{d}\right)\end{array}$ \\
\hline pound per square mile per day $\left(\mathrm{lb} / \mathrm{mi}^{2} / \mathrm{d}\right)$ & 0.17515 & $\begin{array}{l}\text { kilogram per square kilometer per day } \\
\left(\mathrm{kg} / \mathrm{km}^{2} / \mathrm{d}\right)\end{array}$ \\
\hline
\end{tabular}

\section{Supplemental Information}

Concentrations of chemical constituents in water are given in milligrams per liter (mg/L).

Turbidity is given in formazin nephelometric units (FNU).

\section{Abbreviations}

\author{
LOADEST LOAD ESTImator \\ log logarithm \\ $R^{2} \quad$ coefficient of determination \\ USGS U.S. Geological Survey \\ WRTDS Weighted Regressions on Time, Discharge, and Season \\ $<\quad$ less than
}




\title{
Total Phosphorus Loadings for the Cedar River at Palo, lowa, 2009-20
}

\author{
By Jessica D. Garrett
}

\section{Abstract}

In support of nutrient reduction efforts, total phosphorus loads and yields were computed using turbidity-surrogate and LOAD ESTimator (LOADEST) models for the Cedar River at Palo, Iowa, for January 1, 2009, to December 15, 2020. Sample data were used to create a total phosphorus concentration turbidity-surrogate model. Total phosphorus loads also were computed from two streamflow-based LOADEST load models for the periods 2009-20 and 2016-20. The 2009-20 model was used for comparison with previously published loads at this site. The 2016-20 LOADEST model was used with the turbidity-surrogate model before sensor deployment and during periods of missing sensor data to obtain a more complete annual total phosphorus load. This report presents computed loads and methods needed to compute site-specific loads accurately and track annual progress toward nutrient reduction goals within the State.

A comparison of loads from Weighted Regressions on Time, Discharge, and Season; LOADEST; and surrogate models indicated substantial differences at this site among these methods. Changes in both monitoring approaches (highfrequency sensor and surrogate data) and changes in loadcalculation methods present potential challenges in assessing trends, such as assessment of load reduction.

Annual total phosphorus loads for the Cedar River at Palo, Iowa, ranged from 1,370 to 2,360 U.S. short tons per year for 2018-20, based on the turbidity-surrogate model with gaps in sensor data filled with the 2016-20 LOADEST model. Annual total phosphorus yields for the Cedar River ranged from 0.67 to 1.16 pounds per acre per year for 2018-20. Although this load estimate is lower than previous estimates for the benchmark period of 2006-10, when normalized by streamflow, nearly all the apparent reduction can be attributed to differences in the load-calculation methods.

\section{Introduction}

The U.S. Geological Survey (USGS) and the City of Cedar Rapids cooperatively studied total phosphorus loads in the Cedar River at Blairs Ferry Road at Palo, Iowa (USGS station 05464420), hereafter referred to as "Cedar River at Palo, Iowa" (fig. 1). The Cedar River is used for recreation, cooling water, as a drinking water supply, and as a receiving body for permitted discharges; however, the Cedar River and nearby rivers have been identified as large contributors of nutrient loads (nitrogen and phosphorus). These high nutrient levels cause eutrophication of local and downstream waterbodies (Mississippi River/Gulf of Mexico Watershed Nutrient Task Force, 2017; Iowa Department of Agriculture and Land Stewardship and others, 2019).

The nutrient reduction strategy in Iowa (Iowa Department of Agriculture and Land Stewardship and others, 2019), as in other Midwest States (Minnesota Pollution Control Agency, 2014; Ohio Environmental Protection Agency and others, 2016; Illinois Environmental Protection Agency and others, 2019), calls for large reductions in nutrient loads. The total phosphorus-reduction goal in Iowa is 45 percent, using the period 1980-96 as the baseline, although initial estimates for the nutrient reduction strategy in Iowa were based on a baseline period of 2000-6 because of greater data availability.

Load-calculation methods based on streamflow and periodic (weekly to monthly) samples using programs such as LOAD ESTimator (LOADEST) or Weighted Regressions on Time, Discharge, and Season (WRTDS) may be able to detect such large changes but may not be accurate enough to assess interim progress toward load reduction goals; load-calculation estimation errors can be substantial, particularly for total phosphorus and other constituents with a strongly positive or logarithmic- (log-) curvilinear relation between concentration and streamflow (Hirsch, 2014; Lee and others, 2016). LOADEST and WRTDS can be applied consistently across large scales to assess regional patterns (Aulenbach and others, 2007; Robertson and others, 2009), but more accurate methods are needed locally to compute site-specific loads and track annual progress toward nutrient reduction goals (Jones and others, 2018; Iowa Department of Agriculture and Land Stewardship and others, 2019).

Surrogates use indirect data intended to provide information about a parameter that is difficult to measure directly, but the association between the surrogate and the parameter of interest is often direct or uncomplicated. Several studies have determined that turbidity can be a good predictor for total phosphorus concentration, that additional parameters associated with dissolved constituents can improve turbidity-based 


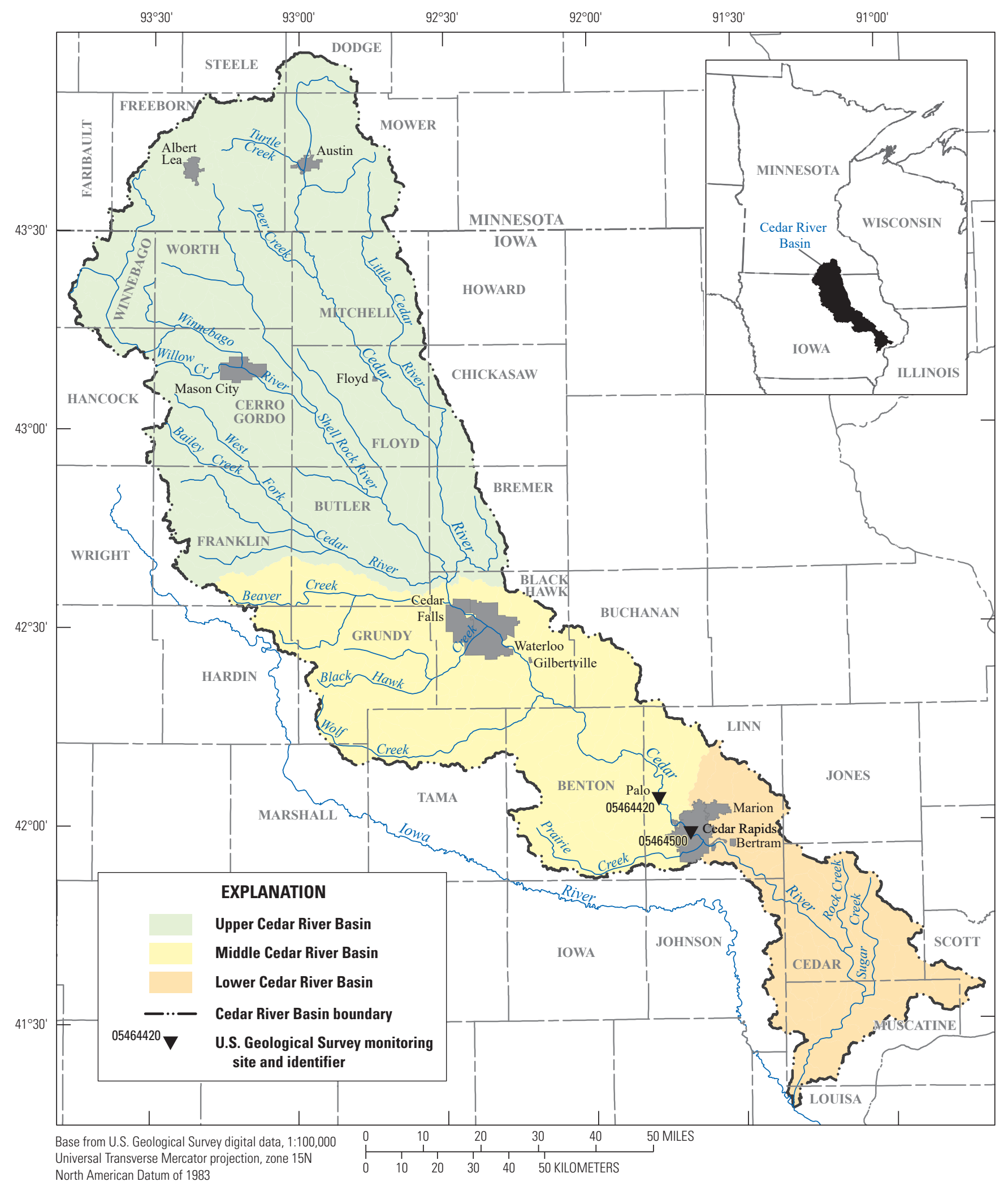

Figure 1. Selected U.S. Geological Survey streamflow-gaging, nutrient, and turbidity monitoring station study sites in the Cedar River Basin in lowa. 
models, and that site specificity is important (Christensen and others, 2006; Rasmussen and others, 2009; Schaepe and others, 2014; Schilling and others, 2017).

\section{Purpose and Scope}

The purpose of this report is to describe the models developed to compute a time series of concentrations and loads of total phosphorus for the Cedar River at Palo, Iowa (USGS station 05464420), for the period beginning in 2009 and to summarize resulting concentrations, loads, and yields. The models are based on empirical statistical regression between turbidity sensor measurements or streamflow and sample results (Garrett, 2019).

Continuous sensor data, streamflow, and sample results are summarized, and regression models and modeled continuous (15-minute or daily interval) data are presented for the Cedar River near Palo, Iowa, for January 1, 2009, to December 15, 2020. Also, the turbidity-surrogate model can be used to compute ongoing total phosphorus concentrations and loads. Continuous turbidity data are summarized through the deployment period beginning August 8, 2018, including a range of seasonal and streamflow event conditions. Sample concentration data for orthophosphate and total phosphorus are presented. Statistical regression models relating turbidity sensor data and sample results are described, including information on model selection and diagnostic procedures. The models and methods presented in this report can be used to compute ongoing time-series total phosphorus concentrations and loads to monitor changes in total phosphorus concentrations and loads in the Cedar River at Palo, Iowa.

\section{Site Information}

Water-quality samples and turbidity data summarized in this report were collected from the Cedar River at Palo, Iowa (fig. 1). This site with a drainage area of 6,342 square miles is collocated with an existing streamflow-gaging station. Mean annual runoff for the selected site is 15.7 inches for the period of streamflow record, which includes water years 2009-20 (U.S. Geological Survey, 2021). A water year is defined as the 12-month period from October 1 to September 30 and is designated by the year in which it ends. Annual runoff for water years 2018-20 was higher than the mean annual runoff for 2009-20, concurrent with deployment of the turbidity sensor, with a range of 18.3-22.8 inches (U.S. Geological Survey, 2021). Water-quality sensor data available at this site include continuous temperature and nitrate concentration beginning October 2012, and specific conductance, dissolved oxygen, and turbidity beginning August 2018.

\section{Methods for Data Collection and Computation}

Instream sensors were used to record turbidity at 15-minute intervals beginning March 2018 at the Cedar River at Palo, Iowa. Discrete water samples from August 2018 to October 2020, concurrent with sensor data, were used for calibration of the turbidity-based total phosphorus concentration model. Discrete water samples collected from April 2009 to October 2020 were used for the calibration of streamflowbased LOADEST models to calculate loads before sensor deployment and to fill periods of missing turbidity data. LOADEST models were fitted using data from two periods: 2009-20 and 2016-20.

\section{Continuous Water-Quality Data Collection and Computation}

Turbidity was monitored using a YSI EXO turbidity sensor (YSI, 2020) in formazin nephelometric units. The EXO sonde including the turbidity sensor was installed in a protective polyethylene pipe suspended from the bridge.

Field inspections of water-quality sensors and data processing followed methods described by Anderson (2005) and Wagner and others (2006). Turbidity standards and deionized water (turbidity free) were used before and after deployment and in the field to detect calibration changes. Cross-sectional data were collected to document general mixing of the stream and to verify data collected at the sensor location represented conditions throughout the channel. Mixing was documented by measuring multiple cross-channel readings of water temperature, specific conductance, $\mathrm{pH}$, dissolved oxygen, and turbidity with a multiparameter sonde. Additionally, samples collected at the deployed sensor location were compared with flow-integrated cross-channel samples.

\section{Water Sample Collection and Analysis}

Discrete water sample data include long-term routine monitoring and targeted samples for 2009-20, the period of available streamflow data for the Cedar River at Palo, Iowa. Discrete water samples were collected monthly from September 2016 to October 2020 and during targeted conditions, such as high streamflow. Monthly samples followed USGS procedures for flow-integrated sample collection and processing described by the USGS "National Field Manual for the Collection of Water-Quality Data" (U.S. Geological Survey, variously dated). A second sample concurrent to the flow-integrated monthly sample was collected from a single cross-section location at the sensor. Targeted samples were collected from a single cross-section location. Concurrent flow-integrated samples were used to assess channel mixing, but only one sample per day was used in the model calibration sets, with preference given to the flow-integrated sample. 
Total Phosphorus Loadings for the Cedar River at Palo, lowa, 2009-20

Samples were analyzed for total phosphorus by the USGS National Water Quality Laboratory in Lakewood, Colorado (Fishman, 1993; O’Dell, 1993; Patton and Kryskalla, 2003). Additional sample data for 2001-14 are described by Kalkhoff (2018), including data from long-term monitoring completed by the Iowa Department of Natural Resources (Iowa Department of Natural Resources, 2020) and synoptic Cedar River Basin studies completed by the USGS (U.S. Geological Survey, 2021).

\section{Methods for Computation of Concentrations and Loads}

Linear regression models for total phosphorus concentrations or loads were fitted to explanatory variables for turbidity or streamflow. A simple regression model (turbidity-surrogate model) for the log-transformed total phosphorus concentration was fitted to the log-transformed explanatory variable turbidity (R Core Team, 2020). LOADEST was used for models of log-transformed total phosphorus loads and log-transformed streamflow (Runkel and De Cicco, 2017). The log-transformed models provide a better linear fit but were retransformed to the original units (the base of the logarithm raised to the power of each side of the equation) so that total phosphorus can be calculated directly. The retransformation can introduce a model bias in the calculated constituent, which was corrected using a nonparametric smearing bias-correction factor (Duan, 1983). Diagnostic tests and plots were considered to verify models had low residual variance, residual plots indicating normality and homoscedasticity, and a mean observed (sampled) to estimated ratio near 1.0 for values during known samples. The observed to estimated ratio was constrained to a maximum range of 0.5-2. Model residuals were inspected for extreme values, which were investigated as potential outliers.

The total phosphorus-turbidity model calibration set included sample results matched to the nearest instantaneous turbidity time-series data, and the resulting continuous total phosphorus concentrations are computed at the same interval as the turbidity time series (typically 15-minute intervals). Continuous and daily mean total phosphorus concentrations from the turbidity-surrogate model (Garrett, 2019) are computed and stored in the USGS National Water Information System (U.S. Geological Survey, 2021). Total phosphorus loads, in U.S. short tons per day, were computed as concentrations, in milligrams per liter, and multiplied by streamflow, in cubic feet per second, as well as a unit conversion factor. The turbidity-surrogate calculation for loads used continuous concentrations and continuous streamflow to compute continuous loads, which were then summarized as daily mean loads.

Streamflow-based LOADEST model calibration sets use sample results matched to daily mean streamflow for two periods, 2009-20 and 2016-20, with resulting total phosphorus loads computed at a daily time step. The 2009-20 LOADEST model was used to compute daily loads from 2009 to 2020 , including during the gap in sampling from October 2014 to
September 2016. The 2016-20 LOADEST model was used to compute daily loads before sensor deployment in August 2018 and during gaps in turbidity data.

Comparisons among loads from the three models and previously published load estimates computed using WRTDS (Kalkhoff, 2018) were used to assess the effect of transitioning among the various models. A comparison also was made with a time series of daily loads obtained by combining loads from the turbidity-surrogate model and the 2016-20 LOADEST model. This comparison provides a more complete time series based primarily on the surrogate model, with gaps filled from the LOADEST results before sensor deployment and during gaps in sensor data.

\section{Water-Quality Sample and Sensor Data}

This section presents summaries of calibration samples used for total phosphorus models and summaries of continuous turbidity sensor data used for total phosphorus load and yield calculations. Model calibration samples should represent the full range of environmental conditions, covering the range of predictor variables (turbidity and streamflow), as well as other conditions affecting the model. To evaluate how well samples represented environmental conditions, the ranges of turbidity and streamflow measurements concurrent with sample collection were compared with the ranges of turbidity and streamflow measurements during the estimation period for each model (table 1, fig. 2). The estimation period for the turbidity-surrogate model was August 8, 2018, to December 15, 2020 (fig. $2 A$ and $B$ ). The estimation periods for the LOADEST models were January 1, 2016, to December 15, 2020 (fig. 2C), and March 26, 2009, to December 15, 2020 (fig. $2 D$ ). The range of sampled streamflow also was compared with long-term (30-year, 1990-2019) streamflow. Long-term statistics were based on streamflow from the downstream streamflow-gaging station with a longer period of record, Cedar River at Cedar Rapids, Iowa (USGS station 05464500), adjusted by a drainage area ratio equal to 0.974 (Hirsch, 1979). Sampled turbidity values did not fully cover the range of observed turbidity values; however, the percentage of time during the estimation period when conditions exceeded the sampled range (high or low) was small (table 1). The range of sampled streamflow covered most of the range of observed streamflow during the estimation period for all models.

Total phosphorus concentrations for turbidity-surrogate calibration samples ranged from 0.081 to 0.438 milligram per liter $(\mathrm{mg} / \mathrm{L})$. Although orthophosphate concentrations generally were much less than total phosphorus concentrations overall (less than $[<] 0.004$ to $0.237 \mathrm{mg} / \mathrm{L}$ ), orthophosphate in individual samples accounted for as much as 91 percent of total phosphorus (mean 38 percent; U.S. Geological Survey, 2021). Sampled streamflow ranged from 1,270 to 46,500 cubic feet per second $\left(\mathrm{ft}^{3} / \mathrm{s}\right)$, compared with a range of 1,170 to $63,300 \mathrm{ft}^{3} / \mathrm{s}$ during the calibration period, or the long-term 
Table 1. Summary of calibration samples and time-series data, Cedar River at Blairs Ferry Road at Palo, lowa (U.S. Geological Survey station 05464420).

[mg/L, milligram per liter; ton/d, U.S. short ton per day; FNU, formazin nephelometric unit; ft³/s, cubic foot per second; --, not applicable; <, less than; LOADEST, LOAD ESTimator]

\begin{tabular}{|c|c|c|c|c|c|c|c|c|}
\hline \multirow[b]{2}{*}{ Statistic } & \multicolumn{3}{|c|}{ Sample conditions } & \multicolumn{2}{|c|}{$\begin{array}{c}\text { Time-series data } \\
\text { matched to samples }{ }^{1}\end{array}$} & \multicolumn{2}{|c|}{$\begin{array}{l}\text { Overall time-series data } \\
\text { during estimation period }{ }^{1}\end{array}$} & \multirow{2}{*}{$\begin{array}{c}\text { 2Long-term } \\
\text { streamflow, } \\
\mathrm{ft}^{3} / \mathrm{s}\end{array}$} \\
\hline & $\begin{array}{c}\text { Total phosphorus, } \\
\text { mg/L }\end{array}$ & $\begin{array}{c}\text { Orthophosphate, } \\
\text { mg/L }\end{array}$ & $\begin{array}{c}\text { Total } \\
\text { phosphorus load } \\
\text { (ton/d) }\end{array}$ & $\begin{array}{l}\text { Turbidity, } \\
\text { FNU }\end{array}$ & $\begin{array}{l}\text { Streamflow, } \\
\mathrm{ft}^{3} / \mathrm{s}\end{array}$ & $\begin{array}{l}\text { Turbidity, } \\
\text { FNU }\end{array}$ & $\begin{array}{c}\text { Streamflow, } \\
\mathrm{ft}^{3} / \mathrm{s}\end{array}$ & \\
\hline \multicolumn{9}{|c|}{ Turbidity-surrogate model, calibration/estimation period August 8, 2018, to December 15, 2020} \\
\hline Maximum & 0.438 & 0.237 & 43.0 & 140 & 46,500 & 730 & 63,300 & 134,000 \\
\hline 99th percentile & -- & -- & -- & -- & 44,000 & 160 & 46,600 & 38,200 \\
\hline 98th percentile & -- & -- & -- & -- & 41,400 & 110 & 42,000 & 28,800 \\
\hline 75th percentile & 0.216 & 0.121 & 13.1 & 32 & 19,000 & 27 & 12,200 & 7,710 \\
\hline Median & 0.167 & 0.069 & 4.51 & 18 & 10,500 & 18 & 6,830 & 3,670 \\
\hline 25 th percentile & 0.140 & 0.009 & 1.45 & 15 & 5,000 & 12 & 3,220 & 1,970 \\
\hline Minimum & 0.081 & $<0.004$ & 0.486 & 3.7 & 1,270 & 2.6 & 1,170 & 261 \\
\hline Count & 24 & 24 & 24 & 24 & 24 & 53,657 & 76,583 & 10,288 \\
\hline \multicolumn{9}{|c|}{ LOADEST model, calibration/estimation period January 1, 2016, to December 15, 2020} \\
\hline Maximum & 0.669 & 0.381 & 74.8 & -- & 80,600 & -- & 86,600 & 134,000 \\
\hline 99th percentile & 0.546 & 0.369 & 56.3 & -- & 60,000 & -- & 43,900 & 38,200 \\
\hline 98th percentile & 0.461 & 0.360 & 43.7 & -- & 45,800 & -- & 34,100 & 28,800 \\
\hline 75th percentile & 0.304 & 0.175 & 11.0 & -- & 15,400 & -- & 11,300 & 7,710 \\
\hline Median & 0.194 & 0.095 & 3.66 & -- & 6,710 & -- & 6,600 & 3,670 \\
\hline 25th percentile & 0.157 & 0.031 & 1.54 & -- & 4,050 & -- & 3,850 & 1,970 \\
\hline Minimum & 0.081 & $<0.004$ & 0.372 & -- & 770 & -- & 525 & 261 \\
\hline Count & 61 & 61 & 61 & -- & 61 & -- & 1,812 & 10,288 \\
\hline \multicolumn{9}{|c|}{ LOADEST model, calibration/estimation period March 26, 2009, to December 15, 2020} \\
\hline Maximum & 1.20 & 1.00 & 74.8 & -- & 80,600 & -- & 86,600 & 134,000 \\
\hline 99th percentile & 0.666 & 0.425 & 43.6 & -- & 45,600 & -- & 40,300 & 38,200 \\
\hline 98th percentile & 0.631 & 0.371 & 42.0 & -- & 40,000 & -- & 30,300 & 28,800 \\
\hline 75th percentile & 0.278 & 0.160 & 6.31 & -- & 11,000 & -- & 9,180 & 7,710 \\
\hline Median & 0.200 & 0.812 & 2.52 & -- & 5,040 & -- & 4,980 & 3,670 \\
\hline 25th percentile & 0.153 & $<0.020$ & 1.03 & -- & 2,490 & -- & 2,320 & 1,970 \\
\hline Minimum & 0.081 & $<0.004$ & 0.372 & -- & 388 & -- & 252 & 261 \\
\hline Count & 130 & 127 & 130 & -- & 130 & -- & 4,284 & 10,288 \\
\hline
\end{tabular}

${ }^{1}$ Instantaneous (15-minute interval) time-series data were used for turbidity-surrogate model summaries; daily mean data were used for LOADEST summaries.

${ }^{2}$ Long-term statistics were based on streamflows from the downstream streamflow-gaging station with a longer period of record, Cedar River at Cedar Rapids, Iowa (U.S. Geological Survey station 05464500$)$, adjusted by a drainage area ratio equal to 0.974 . 

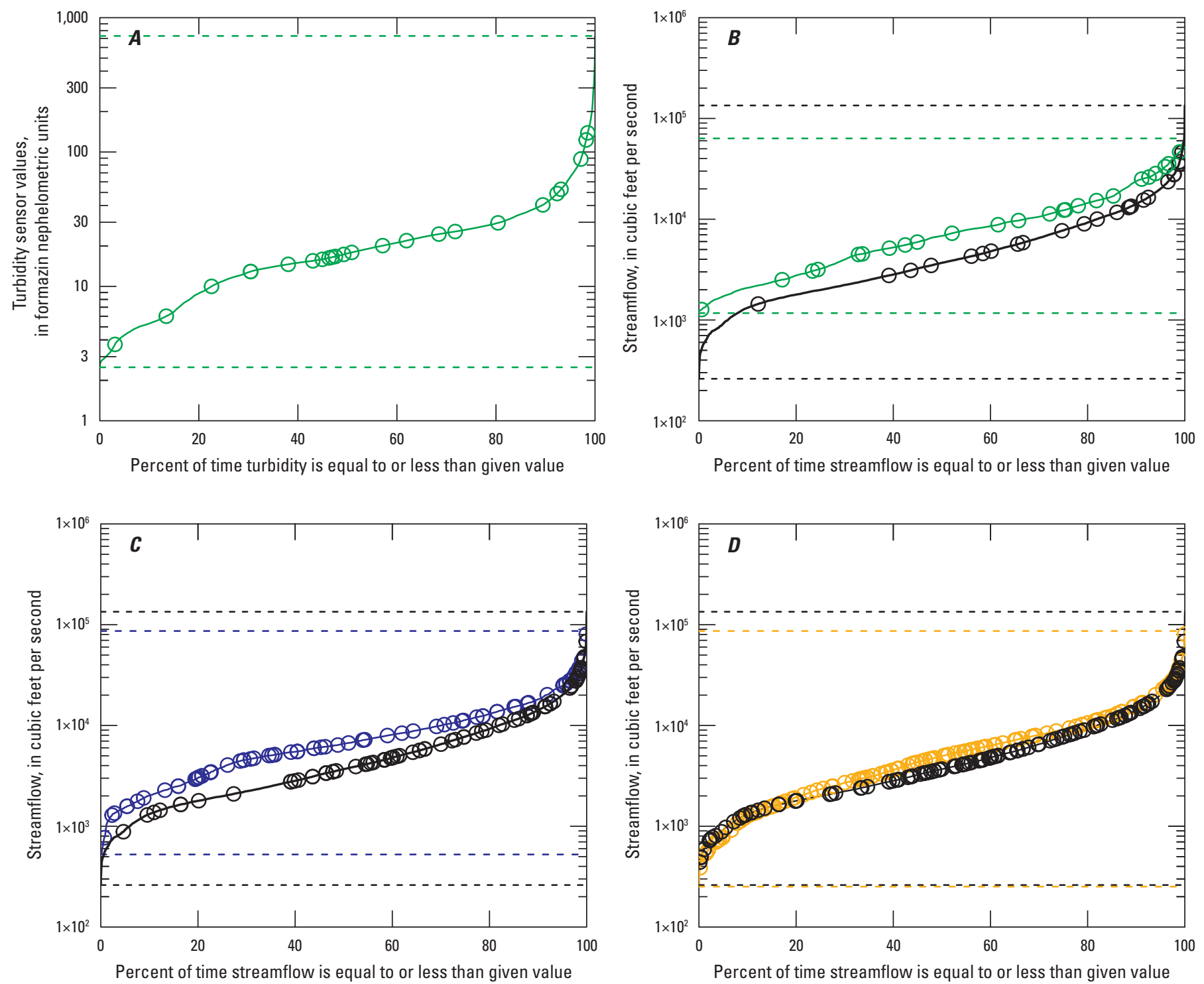

\section{EXPLANATION}

[LOADEST, LOAD ESTimator]

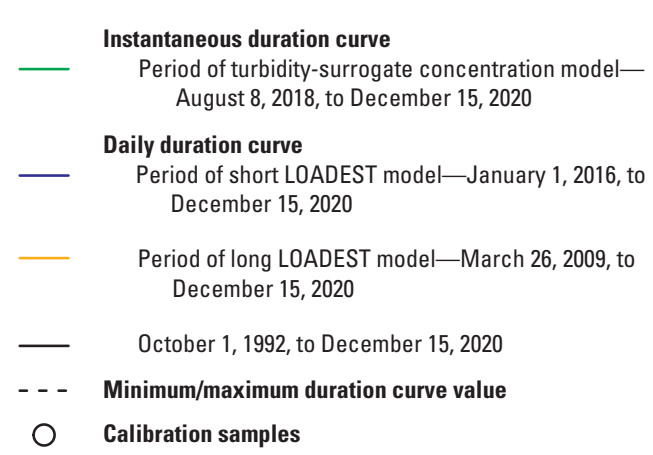

Figure 2. Duration curves with calibration samples, Cedar River at Blairs Ferry Road at Palo, lowa (U.S. Geological Survey station 05464420; U.S. Geological Survey, 2021). $A$, turbidity sensor values for turbidity-surrogate model; $B$, streamflow for turbidity-surrogate model; $C$, streamflow for short LOADEST model; $D$, streamflow for long LOADEST model. 
(30-year) range of 261 to $134,000 \mathrm{ft}^{3} / \mathrm{s}$ (U.S. Geological

Survey, 2021). The maximum sampled streamflow was greater than the 98th percentile of streamflow for the estimation period and greater than the 99th percentile of streamflow for the long-term period.

For calibration samples for the 5-year LOADEST model (January 1, 2016, to December 15, 2020), total phosphorus concentrations ranged from 0.081 to $0.669 \mathrm{mg} / \mathrm{L}$, with orthophosphate concentrations ( $<0.004$ to $0.381 \mathrm{mg} / \mathrm{L}$ ) accounting for as much as 99 percent of total phosphorus (mean 47 percent) (U.S. Geological Survey, 2021). Daily mean streamflow on sampled days ranged from 770 to $80,600 \mathrm{ft}^{3} / \mathrm{s}$, ranging to greater than the 99th percentile relative to either the estimation period or the long-term period.

For the LOADEST model using the longer period (March 26, 2009, to December 15, 2020), total phosphorus concentrations ranged from 0.081 to $1.20 \mathrm{mg} / \mathrm{L}$, with orthophosphate concentrations $(<0.004$ to $1.00 \mathrm{mg} / \mathrm{L})$ accounting for as much as all the total phosphorus (mean 45 percent; Iowa Department of Natural Resources, 2020; U.S. Geological Survey, 2021) in individual samples. Daily mean streamflow on sampled days ranged from 388 to $80,600 \mathrm{ft}^{3} / \mathrm{s}$. The maximum sampled streamflow was greater than the 99th percentile of streamflow for either the estimation period or the longterm period.

Turbidity sensor records beginning August 2018 include data gaps because deployments are seasonal and because of sensor fouling or other problems. Turbidity sensor records include about 37 percent of days for 2018, 53 percent of days for 2019, and 79 percent of days for 2020 (U.S. Geological Survey, 2021). Sensors were not initially deployed until August 8, 2018. Sensors are removed for winter, typically from December through March. The maximum sampled turbidity was between the 98th and 99th percentile of instantaneous (15-minute interval) turbidity values in the estimation period.

\section{Continuous Water-Quality Time-Series Data to Compute Nutrient Loadings}

This section presents models selected for total phosphorus concentrations and loads and summaries of resulting total phosphorus concentrations, loads, and yields. Factors affecting model performance are discussed, such as outliers and extrapolation, particularly relative to annual loads. Resulting total phosphorus concentrations, loads, and yields are summarized for 2018-20 from the turbidity-surrogate model, the 2009-20 LOADEST model, and the 2016-20 LOADEST model and compared with 2002-13 results based on a previously published WRTDS model (Kalkhoff, 2018).

\section{Total Phosphorus Models}

The regression model for total phosphorus concentrations in the Cedar River near Palo, Iowa, was based on turbidity (table 2). Streamflow-based LOADEST models were applied before sensor deployment and during gaps to obtain a more complete record of loads (table 2). LOADEST models generally provide poor estimates of concentration because they are fitted to loads. The total phosphorus concentration model uses the following form:

$$
\begin{aligned}
& \ln (\text { TP conc. })=b_{0}+b_{1} \times \ln (T U R B) \text { or } \\
& \text { TP conc. }=B C F \times \exp \left(b_{0}\right) \times T U R B^{b_{1}},
\end{aligned}
$$

where

$$
\begin{aligned}
& \ln \begin{array}{r}
\text { is the natural logarithm; } \\
\text { is phosphorus concentration, unfiltered, in } \\
\text { milligrams per liter; }
\end{array} \\
& b_{0} \text { and } b_{1} \begin{array}{l}
\text { are fitted parameter estimates; } \\
\text { is turbidity, in units appropriate to sensor used } \\
\text { (formazin nephelometric units); }
\end{array} \\
& B C F \begin{array}{l}
\text { is the model bias-correction factor; and } \\
\text { exp }
\end{array} \\
& \text { denotes the natural exponential function. }
\end{aligned}
$$

Similarly, the LOADEST models use the form:

$$
\ln (\text { TP load })=b_{0}+b_{1} \times \ln (Q)+b_{2} \times \ln (Q)^{2},
$$

where

$$
\begin{array}{cl}
\text { TP load } & \begin{array}{c}
\text { is total phosphorus load, in U.S. short } \\
\text { tons per day; }
\end{array} \\
b_{0} \ldots b_{2} & \begin{array}{l}
\text { are fitted parameter estimates; and } \\
\text { is centered daily mean streamflow, in cubic } \\
\text { feet per second. }
\end{array}
\end{array}
$$

Streamflow terms in LOADEST models are centered, so that linear and quadratic terms are orthogonal, to eliminate problems associated with collinear explanatory variables (Runkel and De Cicco, 2017).

The turbidity-surrogate total phosphorus concentration model had a good empirical fit, with a coefficient of determination $\left(R^{2}\right)$ of 0.806 , a root mean square error of 0.209 , and a retransformation bias-correction factor of 1.02 (table 2, fig. 3). The 2009-20 LOADEST total phosphorus load model had a good fit, with an $R^{2}$ value of 0.895 , a root mean square error of 0.171 , and a retransformation bias-correction factor of 1.11 (table 2, fig. 3). The 2016-20 LOADEST total phosphorus load model was similar, with an $R^{2}$ value 0.889 , a root mean square error of 0.186 , and a retransformation bias-correction factor of 1.10 (table 2, fig. 3).

Although calibration samples did not fully cover the range of observed turbidity values, the turbidity-surrogate model was used to extrapolate beyond the sampled range (3.7-140 formazin nephelometric units [FNU], table 1) to 
Table 2. Total phosphorus concentration regression models, Cedar River at Blairs Ferry Road at Palo, lowa (U.S. Geological Survey station 05464420).

$\left[R^{2}\right.$, coefficient of determination; RMSE, root mean square error; BCF, bias-correction factor; $n$, count; ln, natural logarithm; TP conc., total phosphorus concentration, in milligrams per liter; TURB, turbidity, in formazin backscatter ratio units; LOADEST, LOAD ESTimator; TP load, total phosphorus load, in U.S. short tons per day; $Q$, centered streamflow, in cubic feet per second.]

\begin{tabular}{|c|c|c|c|c|c|c|c|c|c|c|}
\hline \multirow{2}{*}{ Model } & \multirow{2}{*}{ Start date } & \multirow{2}{*}{ End date } & \multirow{2}{*}{ Regression Model } & \multicolumn{4}{|c|}{ Model diagnostics } & \multicolumn{3}{|c|}{ Summary of model input variables } \\
\hline & & & & $R^{2}$ & RMSE & BCF & $n$ & Variable and range & Mean & Median \\
\hline $\begin{array}{l}\text { Turbidity sur- } \\
\text { rogate }\end{array}$ & $8 / 3 / 2018$ & $\begin{array}{r}\text { Current, as of } \\
\text { publication }\end{array}$ & $\begin{array}{l}\ln (\text { TP conc. })=-3.26+0.498 \\
\quad \times \ln (\text { TURB })\end{array}$ & 0.806 & 0.209 & 1.02 & 24 & TURB 3.7-140 & 33 & 18 \\
\hline $\begin{array}{l}\text { 2009-20 } \\
\text { LOADEST }\end{array}$ & $3 / 26 / 2009$ & $12 / 15 / 2020$ & $\begin{array}{l}\ln (\text { TP load })=0.882+1.06 \times \ln (Q) \\
\quad+0.123 \times \ln (Q)^{2}\end{array}$ & 0.895 & 0.171 & 1.11 & 130 & $Q^{1388-80,600}$ & 9,080 & 5,040 \\
\hline $\begin{array}{l}\text { 2016-20 } \\
\text { LOADEST }\end{array}$ & $1 / 1 / 2016$ & $12 / 15 / 2020$ & $\begin{array}{l}\ln (\text { TP load })=1.41+1.18 \times \ln (Q) \\
\quad+0.113 \times \ln (Q)^{2}\end{array}$ & 0.889 & 0.186 & 1.10 & 61 & $Q^{1770-80,600}$ & 12,600 & 6,710 \\
\hline
\end{tabular}

${ }^{1}$ Streamflow ranges presented as actual, uncentered values. 

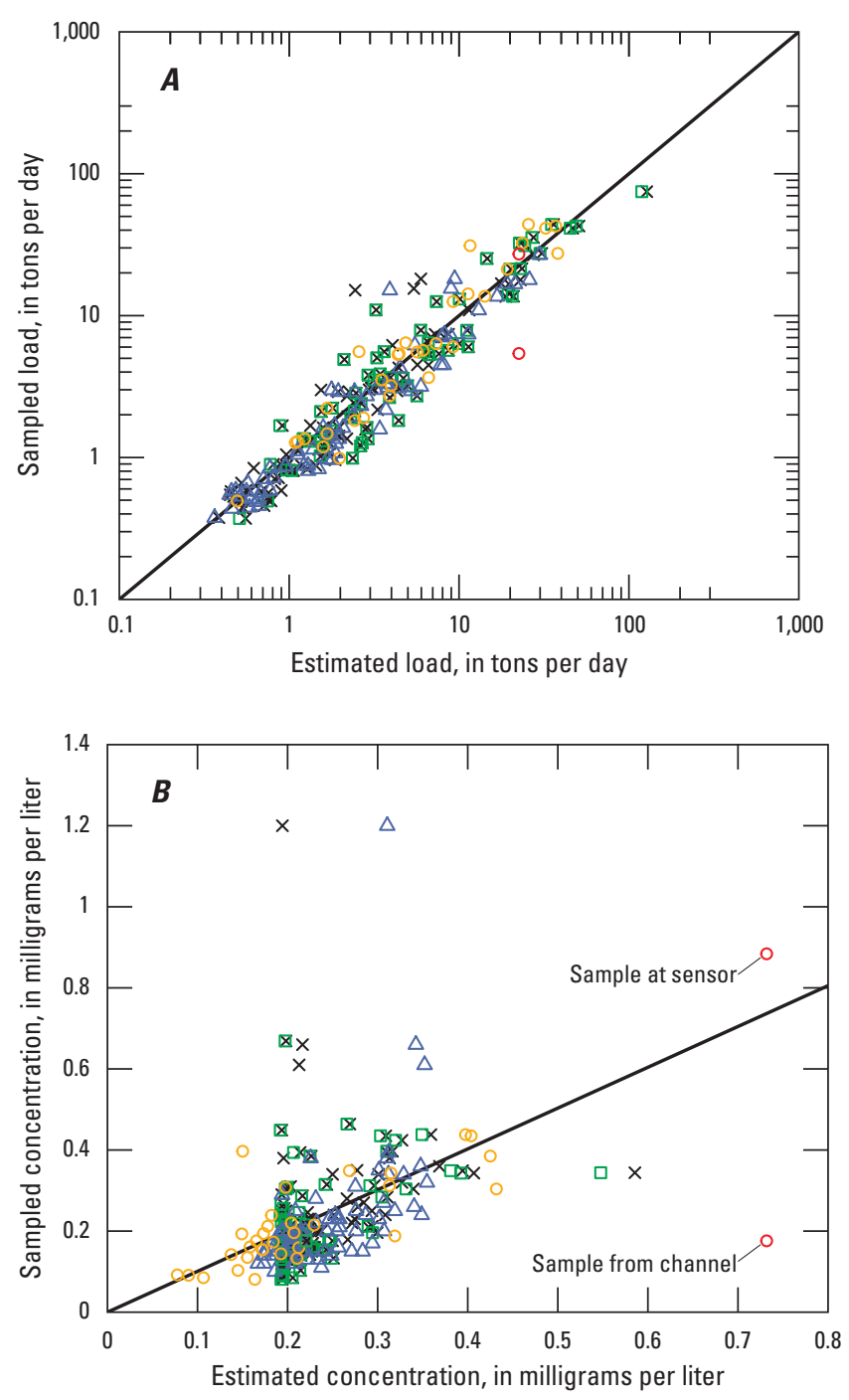

EXPLANATION

[LOADEST, LOAD ESTimator; WRTDS, Weighted Regressions on Time, Discharge, and Season]

$\begin{array}{cl}- & \text { 1:1 line } \\ \times & \text { LOADEST-2009-20 } \\ \square & \text { LOADEST-2016-20 } \\ \Delta & \text { WRTDS-2002-13 (Kalkhoff, 2018) } \\ \circ & \text { Turbidity surrogate } \\ \circ & \text { Turbidity-surrogate excluded outlier }\end{array}$

Figure 3. Sampled and estimated total phosphorus values for four models, Cedar River at Blairs Ferry Road at Palo, lowa (U.S. Geological Survey station 05464420). A, total phosphorus concentrations; $B$, total phosphorus loads.

about 300 FNU. One outlier on May 19, 2019, was removed from the calibration set for the turbidity-surrogate model. The outlier had the highest sampled turbidity of $360 \mathrm{FNU}$ and a total phosphorus concentration in the channel of $0.176 \mathrm{mg} / \mathrm{L}$, but the concentration of the sample collected at the sensor was
$0.884 \mathrm{mg} / \mathrm{L}$. These samples were collected during a period when field observations indicated poor cross-section mixing, with a notable disconnect between data at the sensor location and the main channel. Although this high-turbidity outlier was excluded from the regression, the estimated concentration based on the surrogate model agreed well with the sample collected at the sensor, indicating the model may be appropriately used to extrapolate to higher turbidities (fig. 3). Nevertheless, periods with high turbidity (greater than about $300 \mathrm{FNU}$ ), particularly during noted disconnect between the channel and sensor location, were not used for computation with the turbidity surrogate.

Because calibration samples for the LOADEST models nearly cover the observed range of conditions for the explanatory variable (streamflow), these models were extrapolated beyond the sampled range. No outliers were excluded from the LOADEST total phosphorus load models.

\section{Total Phosphorus Concentrations, Loads, and Yields}

Total phosphorus concentrations, loads, and yields are summarized for the Cedar River at Palo, Iowa, and compared with previously published estimates for this site (table 3; Kalkhoff, 2018). Annual summaries are based on calendar years. Concentrations, loads, and yields are presented for five models. Results from the (1) surrogate model with gaps filled with LOADEST incorporate the valuable high-frequency data from the (2) surrogate model only with the uninterrupted daily time series of the (3) 2016-20 LOADEST model. Results of the (4) 2009-20 LOADEST model provide a historical bridge for comparison with previously published (5) WRTDS results (Kalkhoff, 2018).

From the turbidity-surrogate model, daily mean total phosphorus concentrations computed at the Cedar River at Palo, Iowa, ranged from 0.066 to $0.432 \mathrm{mg} / \mathrm{L}$ (table 3 ). The greatest sample concentration used in the model calibration was $0.438 \mathrm{mg} / \mathrm{L}$ (table 1). The maximum sampled turbidity value in the calibration set was $140 \mathrm{FNU}$ (table 1). The continuous turbidity data exceeded $140 \mathrm{FNU}$ at the site on 17 days, totaling about 190 hours in the nearly 21 months of data collection. However, most of the turbidity data exceeding $140 \mathrm{FNU}$ occurred during periods of disconnect between the channel and sensor location in May 2019, which were not used to compute total phosphorus concentrations. The remaining turbidity record contained fewer than 13 hours with turbidity exceeding 140 FNU. Surrogate-computed total phosphorus daily loads at the Cedar River at Palo, Iowa, site ranged from 0.273 to 38.4 U.S. short tons (tons) per day, and daily yields ranged from 0.0861 to 12.1 pounds per square mile per day (table 3). Annual total phosphorus loads from the surrogate model with gaps filled with LOADEST range from 1,370 to 2,360 tons per year for 2018-20. 
Table 3. Summary of total phosphorus concentrations, loads, and yields for the Cedar River at Blairs Ferry Road at Palo, lowa (U.S. Geological Survey station 05464420).

[mg/L, milligram per liter; ton/d, U.S. short ton per day; lb/mi²/d, pound per square mile per day; lb/acre/yr, pound per acre per year; max, maximum; min, minimum; LOADEST, LOAD ESTimator; WRTDS, Weighted Regressions on Time, Discharge, and Season]

\begin{tabular}{|c|c|c|c|c|c|c|c|c|c|c|c|c|c|c|}
\hline \multirow{2}{*}{ Year } & \multicolumn{4}{|c|}{ Daily mean concentration, mg/L } & \multicolumn{4}{|c|}{ Daily load, ton/d } & \multicolumn{4}{|c|}{ Daily yield, Ib/mi²/d } & \multirow{2}{*}{$\begin{array}{l}\text { Annual } \\
\text { load, ton }\end{array}$} & \multirow{2}{*}{$\begin{array}{c}\text { Annual yield, } \\
\text { lb/acre/yr }\end{array}$} \\
\hline & Mean & Median & Max & Min & Mean & Median & Max & Min & Mean & Median & Max & Min & & \\
\hline \multicolumn{15}{|c|}{ Surrogate model with gaps filled with LOADEST } \\
\hline 2018 & 0.202 & 0.198 & 0.432 & 0.074 & 6.46 & 3.36 & 38.4 & 0.397 & 2.04 & 1.06 & 12.1 & 0.125 & 2,360 & 1.16 \\
\hline 2019 & 0.200 & 0.195 & 0.463 & 0.083 & 6.02 & 3.50 & 77.1 & 0.959 & 1.90 & 1.10 & 24.3 & 0.302 & 2,200 & 1.08 \\
\hline 12020 & 0.174 & 0.178 & 0.404 & 0.066 & 3.74 & 2.01 & 37.1 & 0.273 & 1.18 & 0.634 & 11.7 & 0.0861 & 1,370 & 0.674 \\
\hline \multicolumn{15}{|c|}{ Surrogate model only } \\
\hline 12018 & 0.172 & 0.167 & 0.432 & 0.074 & 8.38 & 4.07 & 38.4 & 1.09 & 2.64 & 1.28 & 12.1 & 0.343 & 3,060 & 1.51 \\
\hline 12019 & 0.189 & 0.181 & 0.427 & 0.083 & 6.14 & 4.66 & 26.9 & 1.10 & 1.94 & 1.47 & 8.48 & 0.348 & 2,240 & 1.11 \\
\hline 12020 & 0.169 & 0.166 & 0.404 & 0.066 & 4.06 & 1.88 & 37.1 & 0.273 & 1.28 & 0.591 & 11.7 & 0.0861 & 1,490 & 0.732 \\
\hline \multicolumn{15}{|c|}{ 2016-20 LOADEST } \\
\hline 2016 & 0.219 & 0.205 & 0.574 & 0.192 & 7.34 & 4.41 & 134 & 1.91 & 2.31 & 1.39 & 42.3 & 0.602 & 2,690 & 1.32 \\
\hline 2017 & 0.209 & 0.203 & 0.295 & 0.192 & 3.94 & 2.79 & 20.7 & 0.395 & 1.24 & 0.879 & 6.52 & 0.125 & 1,440 & 0.709 \\
\hline 2018 & 0.229 & 0.207 & 0.439 & 0.192 & 8.07 & 3.84 & 66.8 & 0.397 & 2.54 & 1.21 & 21.1 & 0.125 & 2,950 & 1.45 \\
\hline 2019 & 0.218 & 0.204 & 0.463 & 0.192 & 6.59 & 4.20 & 77.1 & 0.959 & 2.08 & 1.32 & 24.3 & 0.302 & 2,410 & 1.19 \\
\hline 12020 & 0.212 & 0.199 & 0.392 & 0.192 & 4.62 & 2.27 & 49.0 & 0.725 & 1.46 & 0.715 & 15.4 & 0.229 & 1,690 & 0.832 \\
\hline \multicolumn{15}{|c|}{ 2009-20 LOADEST } \\
\hline 2009 & 0.208 & 0.201 & 0.290 & 0.194 & 3.86 & 2.60 & 18.8 & 0.785 & 1.22 & 0.818 & 5.94 & 0.248 & 1,410 & 0.695 \\
\hline 2010 & 0.214 & 0.199 & 0.421 & 0.194 & 5.48 & 3.05 & 55.6 & 1.13 & 1.73 & 0.962 & 17.5 & 0.357 & 2,000 & 0.986 \\
\hline 2011 & 0.214 & 0.209 & 0.315 & 0.194 & 3.31 & 1.62 & 24.6 & 0.668 & 1.04 & 0.510 & 7.75 & 0.211 & 1,210 & 0.595 \\
\hline 2012 & 0.244 & 0.229 & 0.477 & 0.194 & 1.03 & 0.747 & 5.53 & 0.324 & 0.324 & 0.236 & 1.74 & 0.102 & 376 & 0.185 \\
\hline 2013 & 0.243 & 0.221 & 0.506 & 0.194 & 5.69 & 1.21 & 89.1 & 0.360 & 1.79 & 0.382 & 28.1 & 0.114 & 2,080 & 1.02 \\
\hline 2014 & 0.224 & 0.204 & 0.467 & 0.194 & 4.29 & 1.58 & 73.0 & 0.419 & 1.35 & 0.500 & 23.0 & 0.132 & 1,570 & 0.771 \\
\hline 2015 & 0.207 & 0.199 & 0.323 & 0.194 & 3.32 & 2.18 & 26.5 & 0.622 & 1.05 & 0.688 & 8.36 & 0.196 & 1,210 & 0.598 \\
\hline 2016 & 0.221 & 0.206 & 0.617 & 0.194 & 7.47 & 4.43 & 144 & 1.93 & 2.36 & 1.40 & 45.4 & 0.608 & 2,740 & 1.35 \\
\hline 2017 & 0.212 & 0.206 & 0.315 & 0.194 & 3.98 & 2.80 & 21.0 & 0.447 & 1.25 & 0.884 & 6.63 & 0.141 & 1,450 & 0.716 \\
\hline 2018 & 0.233 & 0.210 & 0.459 & 0.194 & 8.21 & 3.85 & 69.9 & 0.448 & 2.59 & 1.21 & 22.0 & 0.141 & 3,000 & 1.48 \\
\hline 2019 & 0.220 & 0.205 & 0.487 & 0.194 & 6.70 & 4.21 & 81.0 & 0.989 & 2.11 & 1.33 & 25.6 & 0.312 & 2,440 & 1.20 \\
\hline 12020 & 0.215 & 0.203 & 0.407 & 0.194 & 4.66 & 2.28 & 50.8 & 0.760 & 1.47 & 0.720 & 16.0 & 0.240 & 1,710 & 0.841 \\
\hline
\end{tabular}


Table 3. Summary of total phosphorus concentrations, loads, and yields for the Cedar River at Blairs Ferry Road at Palo, lowa (U.S. Geological Survey station 05464420).Continued

[mg/L, milligram per liter; ton/d, U.S. short ton per day; lb/mi²/d, pound per square mile per day; lb/acre/yr, pound per acre per year; max, maximum; min, minimum; LOADEST, LOAD ESTimator; WRTDS, Weighted Regressions on Time, Discharge, and Season]

\begin{tabular}{|c|c|c|c|c|c|c|c|c|c|c|c|c|c|c|}
\hline \multirow{2}{*}{ Year } & \multicolumn{4}{|c|}{ Daily mean concentration, mg/L } & \multicolumn{4}{|c|}{ Daily load, ton/d } & \multicolumn{4}{|c|}{ Daily yield, lb/mi²/d } & \multirow{2}{*}{$\begin{array}{c}\text { Annual } \\
\text { load, ton }\end{array}$} & \multirow{2}{*}{$\begin{array}{c}\text { Annual yield } \\
\text { Ib/acre/yr }\end{array}$} \\
\hline & Mean & Median & Max & Min & Mean & Median & Max & Min & Mean & Median & Max & Min & & \\
\hline \multicolumn{15}{|c|}{ WRTDS (Kalkhoff, 2018) } \\
\hline 2002 & 0.203 & 0.209 & 0.291 & 0.148 & 1.54 & 1.22 & 8.42 & 0.310 & 0.484 & 0.384 & 2.66 & 0.0977 & 560 & 0.276 \\
\hline 2003 & 0.209 & 0.211 & 0.348 & 0.148 & 1.88 & 0.623 & 17.7 & 0.221 & 0.592 & 0.196 & 5.59 & 0.0698 & 686 & 0.338 \\
\hline 2004 & 0.229 & 0.219 & 0.554 & 0.150 & 4.51 & 1.80 & 89.6 & 0.226 & 1.42 & 0.567 & 28.3 & 0.0713 & 1,650 & 0.813 \\
\hline 2005 & 0.206 & 0.207 & 0.395 & 0.149 & 2.55 & 1.53 & 26.4 & 0.389 & 0.805 & 0.481 & 8.33 & 0.123 & 931 & 0.459 \\
\hline 2006 & 0.199 & 0.199 & 0.334 & 0.147 & 2.22 & 1.28 & 14.7 & 0.554 & 0.700 & 0.405 & 4.63 & 0.175 & 810 & 0.399 \\
\hline 2007 & 0.227 & 0.210 & 0.440 & 0.153 & 5.19 & 2.92 & 32.8 & 0.880 & 1.64 & 0.922 & 10.4 & 0.277 & 1,890 & 0.933 \\
\hline 2008 & 0.237 & 0.204 & 0.744 & 0.157 & 10.2 & 1.76 & 268 & 0.559 & 3.22 & 0.556 & 84.6 & 0.176 & 3,740 & 1.84 \\
\hline 2009 & 0.220 & 0.219 & 0.427 & 0.162 & 4.27 & 2.84 & 24.8 & 0.679 & 1.35 & 0.897 & 7.83 & 0.214 & 1,560 & 0.769 \\
\hline 2010 & 0.237 & 0.220 & 0.626 & 0.164 & 6.68 & 3.19 & 82.7 & 0.941 & 2.11 & 1.01 & 26.1 & 0.297 & 2,440 & 1.20 \\
\hline 2011 & 0.232 & 0.212 & 0.478 & 0.168 & 4.10 & 1.72 & 37.2 & 0.550 & 1.29 & 0.541 & 11.7 & 0.173 & 1,500 & 0.738 \\
\hline 2012 & 0.265 & 0.258 & 0.408 & 0.186 & 1.21 & 0.781 & 6.84 & 0.277 & 0.382 & 0.246 & 2.16 & 0.0874 & 444 & 0.219 \\
\hline 2013 & 0.264 & 0.252 & 0.515 & 0.177 & 6.65 & 1.30 & 88.3 & 0.330 & 2.10 & 0.409 & 27.9 & 0.104 & 2,430 & 1.20 \\
\hline
\end{tabular}

${ }^{1}$ Summaries presented include incomplete years for surrogate model without gaps filled and incomplete records for 2020 for all models. 
Because LOADEST models are fitted to loads, these models provide less reliable estimates of concentration; however, the comparison of observed and estimated loads from the LOADEST models is important to assess model performance, particularly model bias and extrapolation (Hirsch, 2014). Daily loads from the 2016-20 model ranged from 0.395 to 134 tons per day, and loads from the 2009-20 model ranged from 0.324 to 144 tons per day (table 3). The range of observed loads (daily load computed from sample concentration and daily mean streamflow) was 0.372 to 74.8 tons per day for both the 2016-20 and 2009-20 models (table 1). Concentrations from the 2016-20 LOADEST model ranged from 0.192 to $0.574 \mathrm{mg} / \mathrm{L}$, and concentrations from the 2009-20 model ranged from 0.194 to $0.617 \mathrm{mg} / \mathrm{L}$, compared with sample ranges of 0.081 to $0.669 \mathrm{mg} / \mathrm{L}$ and 0.081 to $1.20 \mathrm{mg} / \mathrm{L}$, respectively (table 3 , table 1 ). The maximum sampled streamflow of $80,600 \mathrm{ft}^{3} / \mathrm{s}$ was used in the calibration set for both LOADEST models, compared with a maximum daily mean streamflow of $86,600 \mathrm{ft}^{3} / \mathrm{s}$ for either period. The daily mean streamflow exceeded the maximum sampled streamflow once in the period of record for the streamflow-gaging station, during the same event as the maximum sampled streamflow in September 2016.

The statewide baseline (1980-96) total phosphorus load is about 23,800 tons per year (equivalent to an annual statewide yield of 1.32 pounds per acre per year [lb/acre/yr]), and a 45-percent reduction would require an annual statewide total phosphorus yield of $0.73 \mathrm{lb} / \mathrm{acre} / \mathrm{yr}$ to achieve this goal (Iowa
Department of Agriculture and Land Stewardship and others, 2019). A second historical period, or benchmark period, used for the statewide reduction goal is $2006-10$ because sufficient monitoring data are available to calculate annual total phosphorus transport from all major rivers that drain from Iowa (Iowa Department of Agriculture and Land Stewardship and others, 2019). Mean annual statewide total phosphorus yield for the benchmark period was $1.08 \mathrm{lb} / \mathrm{acre} / \mathrm{yr}$. Specific to the Cedar River at Palo, mean annual loads during the 2006-10 benchmark period were 2,088 tons, or a yield of 1.03 pounds per acre (Kalkhoff, 2018; table 3; fig. 4). Similar to statewide data availability, data are not available to compute loads for the 1980-96 baseline period for the Cedar River at Palo.

The overlapping model periods provide some information about transitioning among the different models. Annual loads reported from WRTDS were a mean of 15 percent greater than annual loads computed from LOADEST for 2009-13. LOADEST results were similar (less than a 2-percent difference) for 2016-20 regardless of which calibration period was used. The 2018-20 loads from LOADEST alone were 16 percent greater than loads from the combined turbidity-surrogate and LOADEST model. Based on these comparisons, transitioning from WRTDS to LOADEST and then to the combined turbiditysurrogate LOADEST model, nearly 30 percent of an apparent reduction in load may be due to changes in sample collection through time and the mathematical load model selection. Although computation of loads using surrogates or highfrequency sampling, such as with nitrate sensors or phosphate

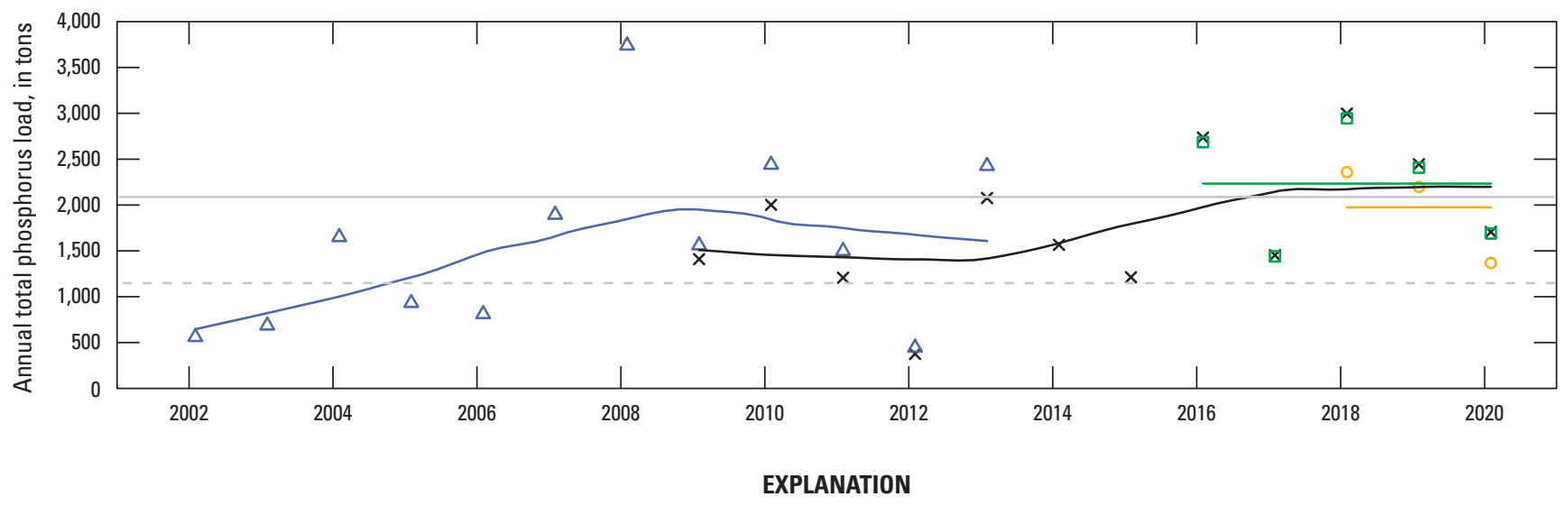

[LOADEST, LOAD ESTimator; WRTDS, Weighted

Regressions on Time, Discharge, and Season]

$\begin{array}{ll}- & \text { Phosphorus-reduction benchmark period-2006-10 (Kalkhoff, 2018) } \\ --- & \text { Phosphorus-reduction target from benchmark } \\ \rightarrow & \text { LOADEST-2009-20 } \\ \square & \text { LOADEST-2016-20 } \\ \square & \text { WRTDS } \\ - & \text { Turbidity surrogate-filled }\end{array}$

Figure 4. Annual total phosphorus loads relative to phosphorus-reduction benchmark and 45-percent reduction goal (WRTDS loads from Kalkhoff, 2018). 
analyzers, is considered more accurate, the change in methods presents challenges for trends assessment (such as assessment of load reduction goals).

Although it is important to assess the reduction of loads overall, runoff-transport relations are an additional tool to evaluate progress of nutrient reduction while controlling for effects of interannual streamflow variability or trends (Kalkhoff, 2018). A uniform reduction in yield over a range of streamflow conditions will result in a lower slope of the runoff-transport fit line (fig. 5). Although normalizing for changes in flow (as in the runoff and yield plots) allows for assessment of progress despite changes in flow, the reductions in actual loads are needed, including effects of changes in flow. Changes in flow may mask improvement in loads for a given streamflow, but load reduction is still needed even if streamflow is increasing. Changes in data collection and load computation methods also may mask or exacerbate perceived environmental changes. A comparison of loads presented in this report indicated a nearly 30-percent adjustment is needed

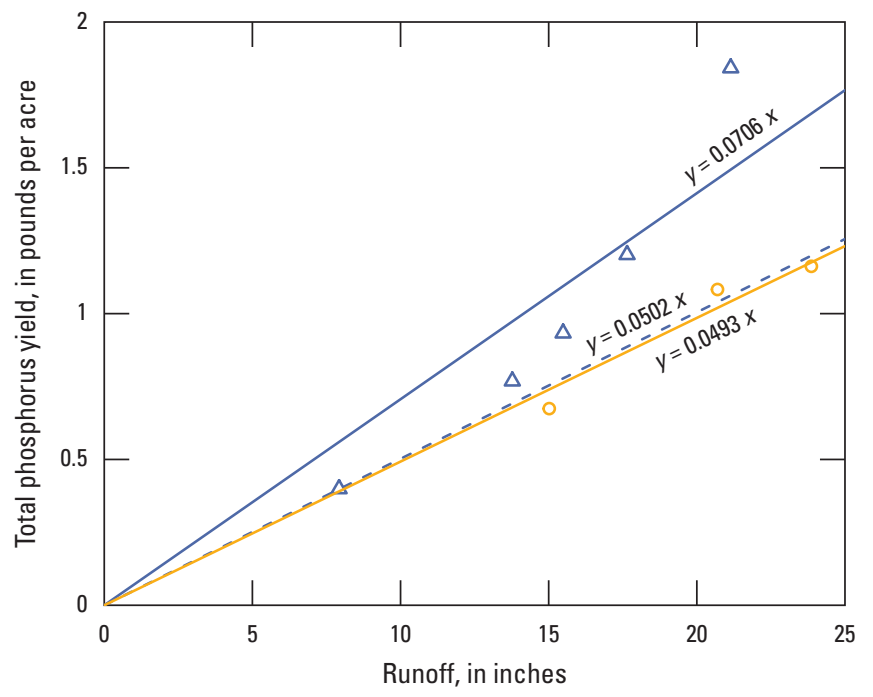

EXPLANATION

[WRTDS, Weighted Regressions on Time, Discharge, and Season; LOADEST, LOAD ESTimator; $y$, total phosphorus yield, in pounds per acre; $X$, runoff, in inches]

Fit line

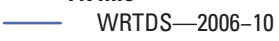

- - - WRTDS - 2006-10, method adjusted

— Combined turbidity-surrogate and LOADEST model

Annual runoff

$\triangle \quad$ WRTDS-2006-10

- Combined turbidity-surrogate and LOADEST model

Figure 5. The relation between annual runoff and total phosphorus yield from the Cedar River at Blairs Ferry Road at Palo, lowa (U.S. Geological Survey station 05464420; WRTDS results from Kalkhoff, 2018). for transitioning among the different models. For 2018-20, the slope was 0.0493 based on yields from the combined turbiditysurrogate and LOADEST model (fig. 5). The slope for the benchmark period 2006-10 was 0.0706 using the WRTDS model. When adjusted for changes in load computation methods, however, the slope is 0.0502 , indicating little change in loads when normalized for streamflow and accounting for changes in load computation methods.

\section{Summary}

In support of nutrient reduction strategies, total phosphorus loads and yields were computed based on continuously monitored turbidity sensor data for more accurate calculations compared with methods based on periodic sample collection and continuous streamflow. Instream sensors recorded continuous turbidity in the Cedar River at Palo, Iowa, collocated with a continuous streamflow-gaging station during 2018-20. Sensor installation, maintenance, and records processing followed U.S. Geological Survey protocols including field data collection to verify that data accurately represent stream conditions. Surrogate models at the Cedar River at Blairs Ferry Road at Palo, Iowa (U.S. Geological Survey station 05464420), described relations between total phosphorus concentrations from discrete samples and continuous sensor data to allow computation of continuous total phosphorus concentrations. Streamflow-based LOAD ESTimator (LOADEST) load models for the periods 2009-20 and 2016-20 were calibrated using samples within each period. The 2016-20 LOADEST results also were used with the turbidity-surrogate loads to generate a more complete annual load by using the LOADEST results before sensor deployment and during gaps in sensor data. The turbidity-based concentration model had a good empirical fit (coefficient of determination $=0.81$ ). The LOADEST models (coefficients of determination $=0.90$ and 0.89 ) were fitted to loads.

A comparison of the longer period LOADEST model with previously published loads using Weighted Regressions on Time, Discharge, and Season indicated the Weighted Regressions on Time, Discharge, and Season model was consistently greater by about 15 percent of annual loads for years computed for both models (2009-13). Although there was little difference (less than 2 percent) between the LOADEST models during comparison years (2016-20), the 2016-20 LOADEST results were about 16 percent greater than the combined turbidity-surrogate and LOADEST result (comparison years 2018-20). Accurate calculations are needed to track annual progress toward nutrient reduction goals at specific sites and across the State, but the comparison of load computation methods at this site highlights challenges in assessing environmental trends during changes in data collection (periodic samples to high-frequency sensor data) and in computational approaches (different load models). 
Annual total phosphorus loads for the Cedar River ranged from 1,370 to 2,360 U.S. short tons (tons) per year for 2018-20, based on the turbidity-surrogate model with gaps filled with the 2016-20 LOADEST model. Annual total phosphorus yields for the Cedar River at Palo, Iowa, ranged from 0.674 to 1.16 pounds per acre per year for 2018-20. Previously published estimates for this site for the 2006-10 period, used as a benchmark for nutrient reduction efforts, indicated a mean annual load of 2,088 tons and a yield of 1.03 pounds per acre. Normalized to streamflow, total phosphorus yields in 2018-20 were lower; however, nearly all the apparent reduction can be attributed to differences in the loadcalculation methods.

\section{References Cited}

Anderson, C.W., 2005, Turbidity (ver. 2.1): U.S. Geological Survey Techniques of Water-Resources Investigations, book 9, chap. A6., sec. 6.7, 55 p., accessed June 5, 2020, at https://doi.org/10.3133/twri09A6.7.

Aulenbach, B.T., Buxton, H.T., Battaglin, W.A., and Coupe, R.H., 2007, Streamflow and nutrient fluxes of the Mississippi-Atchafalaya River Basin and subbasins for the period of record through 2005: U.S. Geological Survey Open-File Report 2007-1080, accessed June 5, 2020, at https://doi.org/10.3133/ofr20071080.

Christensen, V.G., Graham, J.L., Milligan, C.R., Pope, L.M., and Ziegler, A.C., 2006, Water quality and relation to tasteand-odor compounds in the North Fork Ninnescah River and Cheney Reservoir, south-central Kansas, 1997-2003: U.S. Geological Survey Scientific Investigations Report 2006-5095, 43 p., accessed June 5, 2020, at https://doi.org/ $10.3133 / \operatorname{sir} 20065095$.

Duan, N., 1983, Smearing estimate-A nonparametric retransformation method: Journal of the American Statistical Association, v. 78, no. 383, p. 605-610, accessed June 5, 2020, at https://doi.org/10.1080/01621459.1983.10478017.

Fishman, M.J., ed., 1993, Methods of analysis by the U.S. Geological Survey National Water Quality LaboratoryDetermination of inorganic and organic constituents in water and fluvial sediments: U.S. Geological Survey Open-File Report 93-125, 217 p., accessed June 5, 2020, at https://doi.org/10.3133/ofr93125.

Garrett, J.D., 2019, The use of continuous water-quality time-series data to compute nutrient loadings for selected Iowa streams, 2008-17: U.S. Geological Survey Scientific Investigations Report 2019-5054, 31 p., accessed June 5, 2020, at https://doi.org/10.3133/sir20195054.
Hirsch, R.M., 1979, An evaluation of some record reconstruction techniques: Water Resources Research, v. 15, no. 6, p. 1781-1790, accessed December 2016 at https://doi.org/ 10.1029/WR015i006p01781.

Hirsch, R.M., 2014, Large biases in regression-based constituent flux estimates - Causes and diagnostic tools: Journal of the American Water Resources Association, v. 50, no. 6, p. 1401-1424, accessed June 5, 2020, at https://doi.org/ 10.1111/jawr.12195.

Illinois Environmental Protection Agency, Illinois Department of Agriculture, and University of Illinois Extension, 2019, Illinois nutrient loss reduction strategyBiennial report 2019: Springfield, Illinois, Illinois Environmental Protection Agency, 179 p., accessed June 5, 2020, at https://www2.illinois.gov/epa/topics/water-quality/ watershed-management/excess-nutrients/Pages/nutrientloss-reduction-strategy.aspx.

Iowa Department of Agriculture and Land Stewardship, Iowa Department of Natural Resources, and Iowa State University College of Agriculture and Life Sciences, 2019, Iowa Nutrient Reduction Strategy_2017-18 annual progress report: Ames, Iowa, Iowa State University, accessed June 5, 2020, at http:/www.nutrientstrategy. iastate.edu/documents.

Iowa Department of Natural Resources, 2020, AQuIAWater Quality Monitoring: Iowa Department of Natural Resources Water Quality Monitoring and Assessment section web page, accessed June 5, 2020, at https://programs. iowadnr.gov/aquia/.

Jones, C.S., Davis, C.A., Drake, C.W., Schilling, K.E., Debionne, S.H.P., Gilles, D.W., Demir, I., and Weber, L.J., 2018, Iowa statewide stream nitrate load calculated using in situ sensor network: Journal of the American Water Resources Association, v. 54, no. 2, p. 471-486, accessed June 5, 2020, at https://doi.org/10.1111/1752-1688.12618.

Kalkhoff, S.J., 2018, Transport of nitrogen and phosphorus in the Cedar River Basin, Iowa and Minnesota, 2000-15: U.S. Geological Survey Scientific Investigations Report 2018-5090, 44 p. [Also available at https://doi.org/10.3133/ $\operatorname{sir} 20185090$.

Lee, C.J., Hirsch, R.M., Schwarz, G.E., Holtschlag, D.J., Preston, S.D., Crawford, C.G., and Vecchia, A.V., 2016, An evaluation of methods for estimating decadal stream loads: Journal of Hydrology (Amsterdam), v. 542, p. 185-203, accessed June 5, 2020, at https://doi.org/10.1016/j.jhydrol. 2016.08.059.

Minnesota Pollution Control Agency, 2014, Minnesota nutrient reduction strategy: Minneapolis, Minnesota, Minnesota Pollution Control Agency, 348 p., accessed June 5, 2020, at https://www.pca.state.mn.us/water/nutrient-reductionstrategy. 
Mississippi River/Gulf of Mexico Watershed Nutrient Task Force, 2017, Mississippi River/Gulf of Mexico Watershed Nutrient Task Force-2015 Report to Congress: Washington, D.C., U.S. Environmental Protection Agency, Office of Wetlands, Oceans and Watersheds, Mississippi River/Gulf of Mexico Nutrient Task Force, 93 p., accessed June 5, 2020, at https:/www.epa.gov/ms-htf/hypoxia-taskforce-reports-congress.

O’Dell, J.W., ed., 1993, U.S. Environmental Protection Agency Method 365.1, revision 2.0-Determination of phosphorus by semi-automated colorimetry: Cincinnati, Ohio, U.S. Environmental Protection Agency, Environmental Monitoring Systems Laboratory, Office of Research and Development, 17 p. [Also available at https:/hero.epa.gov/hero/index.cfm/reference/details/ reference_id/87589.]

Ohio Environmental Protection Agency, Division of Surface Water, Ohio Environmental Protection Agency, Division of Drinking and Ground Waters, Ohio Department of Agriculture, Livestock Environmental Permitting Program, and Ohio Department of Natural Resources, Division of Soil and Water Resources, 2016, Ohio Nutrient Reduction Strategy 2015 addendum: Columbus, Ohio, Ohio Environmental Protection Agency, 53 p., accessed June 5, 2020, at https://epa.ohio.gov/Portals/35/wqs/ONRS addendum.pdf.

Patton, C.J., and Kryskalla, J.R., 2003, Methods of analysis by the U.S. Geological Survey National Water Quality Laboratory-Evaluation of alkaline persulfate digestion as an alternative to Kjeldahl digestion for determination of total and dissolved nitrogen and phosphorus in water: U.S. Geological Survey Water-Resources Investigations Report 2003-4174, 33 p., accessed June 5, 2020, at https://nwql. usgs.gov/WRIR-03-4174.shtml.

R Core Team, 2020, R-A language and environment for statistical computing: Vienna, Austria, R Foundation for Statistical Computing, accessed June 5, 2020, at https://www.R-project.org/.

Rasmussen, P.P., Gray, J.R., Glysson, G.D., and Ziegler, A.C., 2009, Guidelines and procedures for computing time-series suspended-sediment concentrations and loads from in-stream turbidity-sensor and streamflow data: U.S. Geological Survey Techniques and Methods, book 3, chap. C4, 54 p., accessed June 5, 2020, at https://doi.org/ $10.3133 / \mathrm{tm} 3 \mathrm{C} 4$.
Robertson, D.M., Schwarz, G.E., Saad, D.A., and Alexander, R.B., 2009, Incorporating uncertainty into the ranking of SPARROW model nutrient yields from Mississippi/ Atchafalaya River Basin watersheds: Journal of the American Water Resources Association, v. 45, no. 2, p. 534-549, accessed June 5, 2020, at https://doi.org/ 10.1111/j.1752-1688.2009.00310.x.

Runkel, R., and De Cicco, L., 2017, rloadest: River Load Estimation. R package version 0.4 .5 , accessed October 31 , 2019, at https://github.com/USGS-R/rloadest/.

Schaepe, N.J., Soenksen, P.J., and Rus, D.L., 2014, Relations of water-quality constituent concentrations to surrogate measurements in the lower Platte River corridor, Nebraska, 2007 through 2011: U.S. Geological Survey Open-File Report 2014-1149, 16 p., accessed June 5, 2020, at https://doi.org/10.3133/ofr20141149.

Schilling, K.E., Kim, S.-W., and Jones, C.S., 2017, Use of water quality surrogates to estimate total phosphorus concentrations in Iowa rivers: Journal of Hydrology. Regional Studies, v. 12, p. 111-121, accessed October 15, 2018, at https://doi.org/10.1016/j.ejrh.2017.04.006.

U.S. Geological Survey, 2021, USGS water data for the Nation: U.S. Geological Survey National Water Information System database, accessed February 25, 2021, at https://doi.org/10.5066/F7P55KJN.

U.S. Geological Survey, [variously dated], National field manual for the collection of water-quality data: U.S. Geological Survey Techniques of Water-Resources Investigations, book9, chaps. A1-A9. [Also available at https://pubs.water. usgs.gov/twri9A.]

Wagner, R.J., Boulger, R.W., Jr., Oblinger, C.J., and Smith, B.A., 2006, Guidelines and standard procedures for continuous water-quality monitors-Station operation, record computation, and data reporting: U.S. Geological Survey Techniques and Methods, book 1, chap. D3, 51 p. plus 8 attachments, accessed June 5, 2020, at https://doi.org/ 10.3133/tm1D3.

YSI, 2020, EXO user manual, revision K: Yellow Springs, Ohio, YSI, 243 p., accessed December 10, 2020, at https://www.ysi.com/file\%20library/documents/manuals/ exo-user-manual-web.pdf. 

For more information about this publication, contact:

Director, USGS Central Midwest Water Science Center 400 South Clinton Street, Suite 269

lowa City, IA 52240

319-337-4191

For additional information, visit: https://www.usgs.gov/ centers/cm-water

Publishing support provided by the

Lafayette and Rolla Publishing Service Centers 

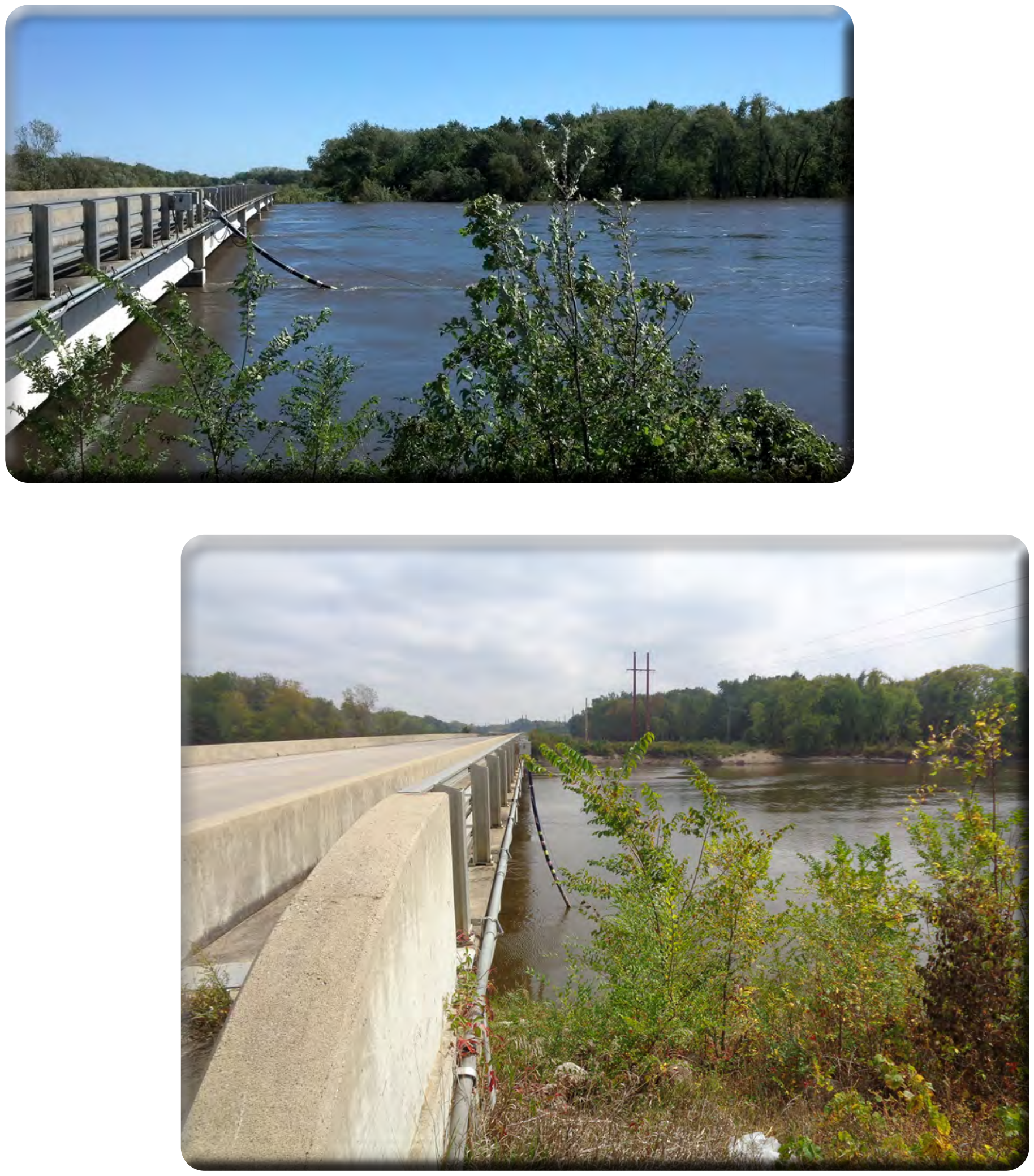

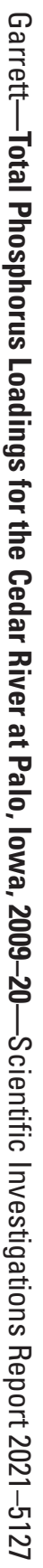

